УДК 342.9

DOI https://doi.org/10.32837/pyuv.v1i3(28).324

\author{
О. М. Бондаренко \\ кандидат юридичних наук, \\ здобувач \\ Науково-дослідного інституту публічного права
}

\title{
ШЛЯХИ ВДОСКОНАЛЕННЯ ПРАВОВОГО РЕГУЛЮВАННЯ ПОЗАСУДОВОГО ВИРІШЕННЯ ПОДАТКОВИХ СПОРІВ
}

Натепер в Україні зроблено багато кроків у напрямі підвищення рівня захисту прав і законних інтересів платників податків, зокрема, шляхом удосконалення механізму розв'язання спірних ситуацій між ними та контролюючими органами. Тим не менше ані позасудова, ані судова форма вирішення податкових спорів не позбавлені певних проблемних моментів, що зумовлює необхідність пошуку шляхів і напрямів покращення їх організаційно-правового підгрунтя. Безпосередньо в дослідженні нами буде присвячена увага визначенню можливих шляхів удосконалення правового регулювання позасудового вирішення податкових спорів, адже, на нашу думку, сама така форма вирішення цього виду спору сьогодні є однією з найперспективніших і водночас недосконалих

Окремі проблемні питання щодо вдосконалення законодавства про вирішення податкових спорів у наукових дослідженнях розглядали: Л. Самсін, М. Кучерявенко, П. Селезень, О. Степашко, Г. Стріяшко, Т. Мацелик, О. Литвин, В. Тильчик, В. Білоус, Д. Цвіра, М. Джафарова, О. Дмитрик, О. Щербакова, О. Дмитрик і багато інших. Однак, незважаючи на чималу кількість наукових розробок, у юридичній літературі відсутнє комплексне дослідження, присвячене вдосконаленню правового регулювання позасудового вирішення податкових спорів.

Саме тому мета статті - визначити шляхи вдосконалення правового регулювання позасудового вирішення податкових спорів.

Спираючись на аналіз чинного законодавства, а також ураховуючи відповідні наукові думки та пропозиції, уважаємо, що з метою підвищення якості й ефективності процедур позасудового вирішення податкових спорів не-обхідно здійснити такі кроки:

1. Запровадити переговорну форму врегулювання податкових конфліктів. Аналізуючи форми й етапи вирішення податкових спорів, ми неодноразово акцентували увагу на тому, що чинне законодавство не містить необхідних засад для реалізації переговорів як засобу врегулювання спору на його початковому етапі (стадії) виникнення (зародження). Така ситуація, очевидно, вимагає конструктивного розв'язання, що зумовлено такими моментами:
- по-перше, однією з основних ідей податкової реформи в нашій державі є встановлення партнерських відносин між державою в особі контролюючих органів і платниками податків. Тобто першочерговими способами управління взаємовідносинами між цими суб'єктами є не владні вказівки, а переконання, взаємодія, консультування;

- по-друге, допоможе зменшити навантаження відповідні адміністративні та судові органи, уповноважені вирішувати податкові спори. Низка конфліктних ситуацій виникає через те, що сторони припускаються помилок у розумінні тих чи інших обставин ситуації, неправильно тлумачать законодавчі положення. Такі проблеми, як правило, не мають суттєвого та складного характеру й цілком можуть бути вирішені між сторонами під час переговорів, тобто без залучення іншого суб'єкта, що наділений юрисдикційними повноваженнями, і початку відповідної адміністративної процедури чи адміністративного процесу;

- по-третє, проведення переговорів сприятиме підвищенню якості й ефективності реалізації адміністративного та (або) судового вирішення податкових спорів, якщо перші (тобто переговори) не призвели до врегулювання розбіжностей. Ідеться про те, що проведення переговорів дає сторонам змогу податкового конфлікту більш чітко та змістовно зрозуміти позицію один одного, обставини й факти, якими кожна 3 них аргументує свою лінію поведінки у спорі. Виходячи із цього, сторони спору можуть більш якісно підготуватися до вирішення податкового спору в адміністративному чи судовому порядку. Крім того, результати отримані в ході переговорів, можуть бути використані сторонами як додаткові докази, аргументи в адміністративній процедурі чи судовому провадженні з вирішення податкового спору.

Означене досить переконливо, на нашу думку, свідчить про доцільність запровадження переговорів як засобу вирішення податкових конфліктів. Для цього необхідно визначити ключові матеріально-правові та процедурні засади проведення переговорів. Звісно, переговори не потребують такої детальної юридичної регламентації, як вирішення податкового спору в адміністративному чи судовому порядку. Тим не менше вимоги щодо основних прав та обов'язків сторін переговорів, 
порядку й оформлення результатів їх проведення мають бути законодавчо врегульовані. Це є необхідним, щоб забезпечити їх цілеспрямованість і послідовність, ефективність і дієвість.

2. Перевести нормативно-правові засади вирішення податкових спорів із площини підзаконного регулювання виключно на рівень закону. Закон - це нормативно-правовий акт вищої юридичної сили, положення якого мають загальний і відносно стабільний характер, тобто розраховані на застосування протягом тривалого часу на широке коло однорідних відносин. Водночас підзаконні акти покликані конкретизувати та розвивати загальні законодавчі положення з урахуванням особливостей окремих різновидів суспільних відносин. Звісно, буде неправильним стверджувати, що сьогодні механізм адміністративного оскарження повністю позбавлений законодавчих засад, оскільки на рівні Податкового кодексу (далі - ПК) України, зокрема в статті 53, закріплено низку важливих аспектів щодо функціонування цього інституту. Однак разом із тим не можна не наголосити на тому, що деякі не менш важливі питання адміністративного оскарження регулюються тільки на підзаконному рівні. Так, наприклад, вимоги щодо оформлення скарг закріплені в спеціальних підзаконних нормативно-правових актах, те саме стосується й вимог щодо форми і змісту рішень адміністративних органів за результатами вирішення податкового спору; основні права й обов'язки сторін спору, а також контролюючого органу, що розглядає податковий спір, закріплені в підзаконних актах, хоча, на нашу думку, ці питання є загальними для будь-якого податкового спору, а отже, повинні мати єдине джерело - відповідний закон.

3. Законодавче закріплення принципів проведення переговорів та адміністративного оскарження. На відміну від Кодексу адміністративного судочинства України, який містить досить широкий і змістовний перелік принципів відправлення адміністративного судочинства, у тому числі у правах про податкові спори, ані в ПК України, ані у відповідних спеціальних підзаконних нормативно-правових актах чітко не визначено кола основних принципів розв' язання податкових конфліктів, вирішення податкових спорів у порядку адміністративного оскарження. Зауважимо, що ми не стверджуємо, що чинне законодавство, яке регулює вирішення податкових спорів у позасудовому порядку, позбавлене принципів функціонування цього інституту, однак більшість із цих принципів розпорошені в тексті низки нормативно-правових актів різної юридичної сили. Крім того, досить часто вони не є очевидними, оскільки не мають чіткого визначення, а лише випливають із тих чи інших законодавчих положень. Така ситуація аж ніяк не відповідає принципу правової визначеності. Цей принцип, пише В. Кернз, являє собою зобов'язання державних владних органів забезпечити легкість з'ясування права тими, до кого воно застосовується, і набуття останніми можливості в разі необхідності скористатися правом, так само як і способом, за допомогою якого воно буде підлягати застосуванню і тлумаченню. Як ухвалив CEC у рішенні у справі Racke, його основна мета полягає в забезпеченні того, що жодна з норм, які приймають державні органи влади, не може бути застосованою до непоінформованих про неї. Означений принцип тісно пов' язаний із принципом законних очікувань, який є наслідком першого. Принцип законних очікувань спрямований на те, щоб у випадках, коли фізична особа переконана, що досягне певного результату, якщо буде діяти відповідно до норм правової системи, забезпечити захист цих очікувань. Однак принцип законних очікувань підлягає певним обмеженням. Перше з них - критерій доцільності. Право Співтовариства захищає законні очікування лише розсудливих та обачних осіб. По-друге, на цей принцип можна посилатися лише у випадку, коли очікування мають законний характер [1, с. 104-110; 2 , с. $158-161 ; 3]$. М. Козюбра розуміє принцип визначеності як неодмінний складник верховенства права, сутністю якого є вимога чіткості підстав, цілей і змісту нормативних приписів, особливо тих із них, які адресовані безпосередньо громадянам, які повинні мати можливість передбачати правові наслідки своєї поведінки [4, с. 30]. Отже, законодавчі положення мають бути чіткими та зрозумілими для тих, кому вони адресовані. Звідси вважаємо, що необхідно закріпити в законодавстві чіткий перелік основних принципів, на яких грунтується й відповідно до яких функціонує механізм позасудового вирішення податкових спорів, щоб кожна сторона, як платник податків, так і контролюючий орган, із якими виник спір, а також контролюючий орган, що розглядає цей спір, чітко розуміли й усвідомлювали ті відправні, засадничі ідеї, відповідно до яких має відбуватися вирішення податкового спору.

4. Урегулювання питання використання медіації для вирішення податкового спору. Відзначимо, що в чинному українському законодавстві не закріплено чітких змістових організаційно-правових засад організації й функціонування інституту медіації як засобу вирішення податкового спору. Переконані, що було б доцільно передбачити в законі, що в разі адміністративного оскарження компетентний контролюючий орган перед тим, як почати розглядати спір, повинен 3'ясувати, чи не бажає платник податків скористатися процедурою медіації для врегулювання наявного податкового спору, із роз'ясненням їі сутності й наслідків. 
5. Підвищення рівня відкритості та прозорості вирішення податкових спорів у порядку адміністративного оскарження. Відповідно до Порядку оформлення і подання скарг платниками податків та їх розгляду контролюючими органами від 21.10.2015 № 916, вирішення скарги платника податків за загальним правилом відбувається в закритому засіданні - це розгляд матеріалів скарги контролюючим органом, який відбувається виключно за участю платника податків скаржника або його уповноважених представників (у тому числі адвокатів), уповноваженого представника Ради бізнес-омбудсмена (за умови прийняття Радою бізнес-омбудсмена до розгляду скарги, поданої платником податків) і представників центрального органу виконавчої влади, що забезпечує формування та реалізує державну фінансову політику [5]. Щодо розгляду матеріалів скарги у відкритому засіданні, то такий відбувається тільки на підставі клопотання платника податків - скаржника, податкового агента або його уповноважених представників (у тому числі адвокатів), а також:

- уповноважених представників центрального органу виконавчої влади, що забезпечує формування та реалізує державну фінансову політику;

- уповноважених представників центрального органу виконавчої влади, який реалізує державну регуляторну політику;

- уповноваженого представника Ради бізнесомбудсмена;

- представників засобів масової інформації [5].

Не ставлячи під сумнів доцільність застосування саме такого підходу до вирішення податкових спорів у порядку адміністративного оскарження, тим не менше вважаємо, що проголошення рішень по справі має відбуватися відкрито з метою забезпечення широкої поінформованості населення про роботу контролюючих органів, а також належного, зокрема громадського, контролю за їхньою діяльністю.

6. Удосконалити законодавче врегулювання правового статусу представників Ради бізнес-омбудсмена та центрального органу виконавчої влади, що забезпечує формування й реалізує державну фінансову політику, під час розгляду податкового спору в порядку адміністративного оскарження. Проблема полягає в тому, що нормотворець, передбачивши можливість їх участі в цій процедурі, жодним чином не визначає їхне становище в ній, їхню роль як учасників цієї процедури. Так, ситуація викликає певні запитання. Наприклад, якщо зазначені суб'єкти виконують роль сторонніх наглядачів за дотриманням законності під час розгляду справи й не приймають безпосередньої участі в її вирішенні по суті, то чи можна тоді такий розгляд називати закритим, як це передбачено в законодавстві; i чому тоді іх присутність на розгляді справи є більш важливо, аніж, скажімо, присутність 3MI, які є одним iз основних складників інституту громадського контролю? Якщо ж представники Ради бізнес-омбудсмена центрального органу виконавчої влади, що забезпечує формування та реалізує державну фінансову політику, беруть участь у вирішенні справи, то якою мірою; чи здатні вони впливати на зміст рішення по справі, якщо так, то чому Порядком як суб'єкт прийняття рішення зазначається тільки посадова особа (керівник, заступник керівника) контролюючого органу, а не відповідна комісія чи колегія у складі цієї посадової особи та вищезазначених представників? Ці питання потребують ретельної уваги нормотворця. На нашу думку, можливо, було б доцільним передбачити, що за загальним правилом вирішення справи відбувається відповідною посадовою особою вищого контролюючого органу. Однак платник податків під час подання скарги на рішення контролюючого органу має право подати клопотання про вирішення спору колегією у складі зазначеної посадової особи представників Ради бізнес-омбудсмена й центрального органу виконавчої влади, що забезпечує формування та реалізує державну фінансову політику.

Отже, резюмуючи викладене в науковому дослідженні, зазначимо, що, звісно, запропоновані нами кроки не вирішують усіх наявних проблемних аспектів механізму досудового вирішення податкових спорів, тим не менше проведення роботи 3 удосконалення законодавчого регулювання щодо вищезазначених проблемних питань має суттєво підвищити якість та ефективність функціонування зазначеного механізму.

\section{Jimepamypa}

1. Кернз В. Вступ до права Європейського Союзу / пер. $з$ англ. Київ : Знання КОО, 2002. С. 104-110.

2. Хартли Т.К. Основы права Европейского Сообщества / пер. с англ. Москва : Закон и право ; ЮНИТИ, 1998. $703 \mathrm{c}$.

3. Богачова Л.Л. Принцип правової визначеності в європейському і національному праві (змістовна характеристика). Теорія і практика правознавства. 2013. Вип. 2. URL: http://nbuv.gov.ua/UJRN/ tipp_2013_2_74.

4. Козюбра М.I. Верховенство права і Україна. Право України. 2012. № 1-2. С. 30-63.

5. Про затвердження Порядку оформлення і подання скарг платниками податків та їх розгляду контролюючими органами : Наказ Мінфіну України від 21.10.2015 № 916. URL: http://zakon.rada.gov.ua/ laws/show/z1617-15. 


\section{Анотація}

Бондаренко О. М. Шляхи вдосконалення правового регулювання позасудового вирішення податкових спорів. - Стаття.

У статті на основі аналізу наукових поглядів учених і норм чинного законодавства України визначено можливі шляхи вдосконалення правового регулювання позасудового вирішення податкових спорів. Констатовано, що запропоновані в статті кроки не вирішують усіх наявних проблемних аспектів механізму досудового вирішення податкових спорів, тим не менше проведення роботи з удосконалення законодавчого регулювання щодо вищезазначених проблемних питань має суттєво підвищити якість та ефективність функціонування зазначеного механізму. Необхідність запровадження переговорної форми врегулювання податкових конфліктів, по-перше, зумовлено тим, що однією з основних ідей податкової реформи в нашій державі є встановлення партнерських відносин між державою в особі контролюючих органів і платниками податків; по-друге, допоможе зменшити навантаження на відповідні адміністративні та судові органи, уповноважені вирішувати податкові спори; по-третє, проведення переговорів сприятиме підвищенню якості й ефективності реалізації адміністративного та (або) судового вирішення податкових спорів, якщо перші (тобто переговори) не призвели до врегулювання розбіжностей. Доведено, що законодавчі положення мають бути чіткими та зрозумілими для тих, кому вони адресовані. Тобто необхідно закріпити в законодавстві чіткий перелік основних принципів, на яких Ірунтується й відповідно до яких функціонує механізм позасудового вирішення податкових спорів, щоб кожна сторона, як платник податків, так i контролюючий орган, із якими виник спір, а також контролюючий орган, що розглядає цей спір, чітко розуміли та усвідомлювали ті відправні, засадничі ідеї, відповідно до яких має відбуватися вирішення податкового спору. Наголошено на доцільності передбачити, що за загальним правилом вирішення справи відбувається відповідною посадовою особою вищого контролюючого органу. Однак платник податків під час подання скарги на рішення контролюючого органу має право подати клопотання про вирішення спору колегією у складі зазначеної посадової особи представників Ради бізнес-омбудсмена й центрального органу виконавчої влади, що забезпечує формування та реалізує державну фінансову політику.
Ключові слова: спір, податковий спір, правове регулювання, позасудове вирішення спору, удосконалення законодавства.

\section{Summary}

Bondarenko O. M. Ways for the improvement of legal regulation of out-of-court settlement of tax disputes. Article.

In the article, based on the analysis of scientific views of scientists and the norms of the current legislation of Ukraine, possible ways of improving the legal regulation of extrajudicial tax disputes. It is stated that the steps proposed in the article do not solve all the existing problematic aspects of the mechanism of pre-trial settlement of tax disputes, but nevertheless, work on improving the legislative regulation regarding the above-mentioned problem issues, should significantly improve the quality and efficiency of the mechanism. The necessity of introducing a negotiated form of tax conflict settlement is conditioned: first, one of the main ideas of tax reform in our country is to establish partnerships between the state, represented by the controlling bodies, and taxpayers; second, it will help reduce the burden on the relevant administrative and judicial authorities empowered to resolve tax disputes; third, the negotiation will improve the quality and efficiency of the administrative and (or) judicial settlement of tax disputes, if the first (ie negotiations) did not lead to the settlement of differences. It has been proven that the legal provisions must be clear and understandable to those to whom they are addressed. That is, it is necessary to establish in the legislation a clear list of the basic principles on which the mechanism for out-of-court settlement of tax disputes is based and according to which. In order that each party, both the taxpayer and the controlling body with which the dispute arose, as well as the controlling body examining the dispute, clearly understood and understood those starting, basic ideas in accordance with which the tax dispute should be resolved. It is emphasized that it is appropriate to provide that, as a general rule, the decision of the case is made by the relevant official of the higher controlling body. However, when filing an appeal against the decision of the supervisory authority, the taxpayer has the right to file a petition for resolution of the dispute by a panel of representatives of the Council of Business Ombudsmen and the central executive body responsible for the formation and implementation of the state financial policy.

Key words: dispute, tax disputes, legal regulation, extrajudicial settlement of a dispute, improvement of legislation. 